\title{
Os Vírus são "singulares" e desafiam os paradigmas da Ciência
}

\section{Viruses are "unique" and challenge the paradigms of science}

Luís Calafate, Universidade do Porto, Portugal (lcalafat@fc.up.pt)

Resumo: A história do progresso do conhecimento científico dos vírus demonstra que a tendência dos investigadores para se prenderem a paradigmas e teorias específicas sobre as causas das doenças, não os deixa ver as ameaças de patógenos conhecidos e desconhecidos (Honigsbaum, 2021). É o caso, por exemplo, da "teoria dos germes" da doença, apresentada pelo bacteriologista alemão Robert Koch e o seu colega francês Louis Pasteur, na década de 1880. O paradigma bacteriológico da gripe humana, ao ser defendido por Richard Pfeiffer em 1892, atrasou durante décadas a compreensão da sua etiologia viral. Infelizmente, raro era o homem de ciência que ousava desafiar a autoridade de Koch e dos seus discípulos.

Neste artigo pretendemos contribuir para a elaboração de uma imagem científica dos vírus, confrontando-a, sempre que necessário, com a ontologia da vida quotidiana. Para Dennett (2021), a imagem científica é algo que se tem de aprender na escola, e a maioria das pessoas adquire um conhecimento superficial da mesma. Não obstante, na nossa relação com os vírus, temos que aprender quais as "coisas" a retirar da nossa ontologia da vida quotidiana e quais as novas categorias a introduzir para criar uma ontologia da imagem científica dos vírus, fundamentando a nossa compreensão destas entidades singulares que desafiam os paradigmas científicos. É neste contexto que a abordagem do processo de produção do conhecimento científico tem sido apontada como de fundamental importância para compreender a Ciência, e a Virologia, como atividade humana historicamente contextualizada.

Palavras-Chave: vírus, paradigmas, ciência, ecologia, virosfera

\begin{abstract}
The history of the progress of scientific knowledge of viruses demonstrates that the tendency of researchers to get caught up in specific paradigms and theories about the causes of diseases does not allow them to see the threats of known and unknown pathogens (Honigsbaum, 2021). This is the case, for example, of the "germ theory" of the disease, presented by the German bacteriologist Robert Koch and his French colleague Louis Pasteur, in the 1880s. The bacteriological paradigm of human flu, when defended by Richard Pfeiffer in 1892, delayed the understanding of its viral etiology for decades. Unfortunately, it was rare the man of science who dared challenge the authority of Koch and his disciples.
\end{abstract}


In this article, we intended to contribute to the elaboration of a scientific image of viruses, confronting it, whenever necessary, with the ontology of everyday life. For Dennett (2021), the scientific image is something that has to be learned at school, and most people acquire a superficial knowledge of it. Nevertheless, in our relationship with viruses, we have to learn what "things" to remove from our ontology of everyday life and what new categories to introduce to create an ontology of the scientific image of viruses, underpinning our understanding of these unique entities that challenge scientific paradigms. It is in this context that the approach to the process of production of scientific knowledge has been identified as being of fundamental importance to understanding Science and Virology has a historically contextualized human activity.

Keywords: viruses, paradigms, science, ecology, virosphere

\section{Introdução}

A Virologia é uma ciência relativamente recente e mostrou-nos que vivemos num mundo de vírus abundantes e diversificados. Até meados do século XX, os vírus eram um mistério invisível (Parreira \& Piedade, 2016). Atualmente, sabemos que os vírus são intervenientes dinâmicos na ecologia da Terra. Vivem uma espécie de vida por procuração. São parasitas intracelulares, ou seja, dependem da célula hospedeira, no que diz respeito às matérias-primas brutas e à energia necessária à síntese dos ácidos nucleicos, à síntese de proteínas, ao seu processamento e transporte, assim como a todas as outras atividades bioquímicas que lhes permitem multiplicar-se e se propagar.

Os vírus tiram partido do aparelho de tradução das células que infetam para sintetizar as proteínas que codificam. Recorrendo a uma analogia das ciências da computação, Maynard Smith \& Szathmáry (2007) comparam os vírus a programas que dão ao computador instruções para fazer novas, e numerosas, cópias virais, mesmo que o computador seja destruído durante esse processo. Por exemplo, os retrovírus (como o da imunodeficiência humana, o VIH/SIDA) recebem esse nome pela capacidade de converter o código genético registado no seu RNA numa versão registada em DNA, pela ação de uma enzima reversiva. Possuem no seu RNA as instruções para poder sintetizar, quando infetam uma célula, uma maquinaria específica, a enzima transcriptase reversa (RT). Uma vez produzida, a RT produz uma molécula de DNA utilizando como molde o RNA viral. Este invasor consegue integrar-se na molécula de DNA do hospedeiro. Assim, a mensagem de certos vírus pode acabar por se incorporar na informação do computador central. Esta incorporação garante a sobrevivência do vírus em letargia. Em certas circunstâncias, 
o vírus pode ser reativado. É o caso, por exemplo, do vírus da varicela-zóster, que geralmente nos afeta na infância. Longe de desaparecer, integra-se em certas células nervosas e pode reaparecer, no futuro, como o incómodo herpes, provocando todo o desconforto característico das erupções de pele.

Para Kuhn (1980) a história da ciência mostra mudanças que ocorreram no domínio concetual através do qual os cientistas visualizavam a realidade. Kuhn prestou um grande serviço ao evidenciar o papel fundamental das conceções de uma comunidade científica na atividade de pesquisa. Ele desviou a atenção dos investigadores, interessados no problema do conhecimento, do estudo dos métodos lógicos de descoberta científica para os esquemas sociais e concetuais que dirigem a investigação científica. Depois de Kuhn os homens de ciência passaram a observar o mundo em função das teorias que aceitam como válidas. Antes de Kuhn julgavase que o princípio da organização das teorias científicas era pura e simplesmente lógico. Para ele, a mudança concetual ou de paradigma, como designou, não se processa logicamente (Calafate, 1984).

\section{O vírus do mosaico do tabaco: a descoberta da "virosfera"}

Como os seres humanos, as plantas também sofrem doenças e epidemias. Segundo Claude Chastel (2007), o vírus do mosaico do tabaco (VMT), que provoca doenças em plantas em todo o mundo, foi o primeiro a ser identificado, após experiências realizadas por volta de 1898 pelo engenheiro químico holandês Martinus Beijerinck, no seguimento do trabalho desenvolvido pelo então jovem botânico russo Dimitri Ivanovski em 1887.

Ainda como estudante na Universidade de São Petersburgo, em 1887, Dimitri Ivanovski foi contratado pelo Estado Russo para estudar as causas de uma doença que atacava as plantações de tabaco do sul da Rússia. As manchas em forma de mosaico nas folhas, deixavam-nas atrofiadas e murchas. Numa tese, defendida em 1888, e apresentada à Academia das Ciências de São Petersburgo em 1892, Ivanovski mostrou que a seiva extraída de folhas infetadas continha um agente infecioso que podia ser transmitido, mesmo depois de filtrada por velas de Chamberland. Estes filtros de porcelana não vidrada eram considerados capazes de reter as bactérias (Chastel, 2007).

Já em 1879, os produtores neerlandeses tinham pedido ajuda a um químico alemão, Adolph Mayer, que começou por investigar os elementos do ambiente em que as plantas eram cultivadas - o solo, a temperatura, a luz solar, mas não conseguiu encontrar algo que ajudasse a distinguir as plantas saudáveis das plantas doentes. Todavia, quando extraiu a seiva de plantas doentes e a injetou em plantas saudáveis estas adoeceram. Assim, percebeu que um agente patogénico 
microscópico deveria estar a multiplicar-se no interior da planta do tabaco. De seguida, retirou a seiva de plantas doentes e incubou-a no seu laboratório, verificando o crescimento de colónias de bactérias. Todavia, quando aplicou essas bactérias em plantas saudáveis estas não adoeceram. Após esse fracasso, a sua investigação acabou abandonada e esquecida.

Na sua investigação, Dmitri Ivanovski não identificou bactérias na seiva recolhida, nem antes nem depois da filtração. Todavia, também tentou interpretar esta doença pela presença de uma toxina produzida por bactérias, à semelhança da toxina produzida pela bactéria Corynebacterium diphteriae, descoberta em 1888 por Émile Roux e o seu colaborador Alexandre Yersin. A propriedade essencial dessas toxinas bacterianas é a sua filtrabilidade. Mas Ivanovski nunca encontrou a toxina. Até ao fim da sua vida, pensou estar lidando com uma toxina, uma bactéria ou um esporo (Chastel, 2007).

Em 1898, Martinus Beijerinck repetiu as experiências de Ivanovski e confirmou as suas observações. Mas foi mais além, na interpretação do fenómeno. Após a diluição da seiva e da sua passagem sobre folhas de tabaco, o poder infecioso permanecia. Para Beijerinck, não se tratava de uma bactéria pois ela não podia ser vista ao microscópio, nem de uma toxina, pois a sua atividade diminuiria com as diluições. Ele designou este agente desconhecido por Contagium vivum fluidum (“Um Líquido Vivo Contagioso").

Posteriormente, a microscopia eletrónica revelou que o VMT tem a forma de um bastonete côncavo e mede $300 \mathrm{~nm}$ de comprimento. O microscópio eletrónico foi construído em 1932 por Ernst Ruska e as primeiras fotografias de vírus foram publicadas em 1939 (Pilorge, 1995). Estamos perante um bom exemplo que torna evidente que novos instrumentos, como o microscópio de eletrões, podem ser desenvolvidos numa especialidade e a sua assimilação criar uma crise numa outra.

No séc. XIX a utilização do microscópio comum confirmou a teoria dos germes. Inúmeras doenças humanas, animais e vegetais passaram a ter explicação pelo paradigma um germe uma doença. Assim, no final do séc. XIX era difícil para um cientista conceber agentes infeciosos que não fossem bactérias, fungos ou parasitas. Quando o engenheiro químico Martinus Beijerinck se referiu a uma estrutura, posteriormente identificada como vírus, nomes científicos consagrados, em particular Émile Roux, repudiaram a ideia (Chastel, 2007). Émile Roux, para além de ser o discípulo mais famoso de Louis Pasteur, foi quem criou o Instituto Pasteur.

Na mesma altura em que o jovem botânico russo Dimitri Ivanovski mostrara que a doença do mosaico do tabaco era causada por um agente invisível que passava através dos filtros de porcelana, cujos poros eram demasiado pequenos para deixarem passar bactérias, Richard Pfeiffer, considerado uma autoridade na 
matéria, defendia, desde 1892, que a gripe era transmitida por uma bactéria gramnegativa a que chamou Bacillus influenzae (Honigsbaum, 2021).

A tendência dos investigadores para se deixarem prender a paradigmas e teorias específicas sobre as causas das doenças, muitas vezes, não os deixa ver as ameaças de patógenos conhecidos e desconhecidos. Felizmente, os paradigmas estão constantemente a ser aperfeiçoados por novas observações. Todavia, seguirse-iam ainda muitos anos antes de o paradigma bacteriológico da gripe ser substituído e de a etiologia viral ser descoberta. $\mathrm{O}$ vírus da gripe humana foi isolado desde 1933 e visto pela primeira vez, também, graças à invenção do microscópio eletrónico (Tavares, 2007).

Popper (1978) propõe uma conceção em que a ciência progride através da sucessão de esquemas concetuais ou teorias. Para ele a decisão que leva a aceitar ou a rejeitar uma teoria é baseada em factos decisivos e avaliada por uma lógica rigorosa. Uma teoria científica é admitida não por ser verdadeira, mas por resistir à demonstração da sua falsidade. Portanto, Popper é um filósofo da ciência que dá um lugar central à metodologia da investigação científica praticada pelos cientistas. Ele considera de grande importância o papel dos instrumentos, dos protocolos de pesquisa e dos processos lógicos de inferência científica como um meio de partir das observações para as conclusões.

Podemos dizer que a história das teorias científicas é concebida em analogia com a seleção natural. São as teorias mais adaptadas à explicação dos fenómenos que sobrevivem, até que o mundo dos fenómenos alargue e exija novas teorias (Calafate, 1984). Popper (1978) inverteu a problemática da ciência mostrando que a ciência não progride por acumulação de verdades mas, sobretudo, por eliminação de erros na procura da verdade. Portanto, a objetividade da ciência, assim como o rigor das teorias científicas, não é uma questão individual, própria dos homens da ciência, mas uma questão social que resulta da sua colaboração e da sua crítica mútua. A ciência é um campo sempre aberto onde se submetem à prova não só as teorias, mas também as visões do mundo e os postulados metafísicos (Calafate, 1984).

\section{Durar: a razão de ser dos vírus}

Os agentes patogénicos são um produto da seleção natural e a sua sobrevivência depende da informação. Segundo a teoria darwiniana da evolução, as estratégias dos vírus respondem a um único compromisso: garantir a sua multiplicação (Sonigo, 1995). O seu principal objetivo é sobreviver o tempo suficiente para poder escapar e infetar outro hospedeiro suscetível (Marçal \& Fiolhais, 2020). A morte do hospedeiro é uma má estratégia para um parasita. O agente infecioso que se propaga melhor deixa mais descendentes e acaba favorecido 
pela seleção natural. Para tal, utiliza diferentes estratégias de infeção. Mesmo os vírus empenham-se em estratagemas surpreendentes para enganar, esconder-se ou camuflar-se numa corrida contra os seus concorrentes.

Por exemplo, o vírus ébola imita um fragmento de célula apoptótica a fim de ser "comida" por uma célula fagocitária (que recolhe lixo), apanhando assim uma boleia segura de uma célula que o transportará no corpo (Misasi \& Sullivan, 2014). O vírus Ébola provoca uma infeção aguda, destruindo rapidamente o organismo, segundo uma estratégia de "terra queimada". Esse vírus, responsável por uma febre hemorrágica fulminante, tem letalidade elevadíssima (de 53\% a 88\%). Ao contrário, a infeção crónica causada pelo vírus herpes simplex de tipo 1 (HSV-1) recorre a uma "estratégia ecológica", estabelecendo uma infeção para toda a vida nos hospedeiros. As células infetadas de forma latente estão localizadas em órgãos pouco acessíveis à resposta imunológica. Todavia, esse equilíbrio, aparentemente pacífico, pode ser interrompido.

$\mathrm{O}$ vírus da imunodeficiência humana $(\mathrm{VIH})$ é, do ponto de vista evolucionário, um vírus excecional, pois mata o hospedeiro apenas depois de ter assegurado a sua disseminação em larga escala (Whitfield, 1994). Os investigadores descobriram que o VIH pode infetar secretamente os seres humanos durante décadas, antes de se manifestar numa epidemia viral. Uma estratégia engenhosa assegura a máxima disseminação do vírus. A transmissão, geralmente sexual, é direta e eficiente, dado que os vírus nunca têm de passar ao mundo exterior. Quanto ao longo período de incubação, este assegura que a pessoa infetada transmita involuntariamente o vírus a outros parceiros sexuais. Se o vírus provocasse morte rápida, reduziam-se as possibilidades de transmissão a outros hospedeiros.

Os linfócitos T CD4, onde o VIH se esconde, continuam a multiplicar-se. De vez em quando, um linfócito T CD4 infetado cria um lote de VIH novo, que explode para infetar outras células. O sistema imunitário ataca estas novas vagas de vírus sempre que afluem pelo organismo. Assim que o sistema imunitário falha, as pessoas deixam de conseguir defender-se. Esta condição enfraquecida ficou conhecida por síndrome da imunodeficiência adquirida ou SIDA (Zimmer, 2021).

As doenças infeciosas apresentam padrões bastantes diferentes entre si. Por exemplo, as doenças epidémicas não produzem nenhum caso durante muito tempo, depois aparece uma grande onda de casos seguida de mais um intervalo momentâneo. É o caso da gripe, que matou 21 milhões de pessoas no final da Primeira Guerra Mundial (Diamond, 2002).

Segundo Diamond (2002), as doenças infeciosas epidémicas partilham várias características. Propagam-se rápida e eficazmente de uma pessoa infetada para as pessoas saudáveis que estejam na sua proximidade, com o resultado de toda a 
população ficar exposta num curto período de tempo. A muito curto prazo, ou se morre delas ou se recupera completamente. Os que recuperam desenvolvem uma resposta imunitária específica que os tornam imunes durante muito tempo e, possivelmente, para o resto das suas vidas. Os agentes patogénicos que as provocam tendem a não viver no solo ou noutros animais. Estas características aplicam-se a doenças epidémicas agudas como, por exemplo, à varíola, ao sarampo, à rubéola e à papeira. Como o agente patogénico, não pode sobreviver senão nos corpos de pessoas vivas, a doença desaparece, até que uma nova geração de indivíduos atinja a idade suscetível e até que alguém infetado chegue do exterior para desencadear uma nova epidemia.

As doenças infeciosas agudas, que conhecemos em todo o mundo, para persistirem, necessitam de uma população humana suficientemente numerosa, concentrada e fixa, para que uma nova geração de indivíduos suscetíveis esteja disponível para ser infetada. Em suma, estamos a falar de doenças das multidões que não teriam entrado na nossa história sem a invenção da agricultura (Aires, 2020).

Resumindo, as doenças infeciosas representam a evolução em progresso e os agentes patogénicos adaptam-se por seleção natural a novos hospedeiros e vetores. Num novo ambiente, um agente patogénico tem de desenvolver novas maneiras de viver e propagar-se. Nós e os nossos agentes patogénicos travamos uma competição crescente que se traduz numa corrida a armas de destruição. Quando um organismo parasita contacta com um hospedeiro, pela primeira vez, desencadeia uma corrida às armas entre o patógeno e o sistema imunitário do hospedeiro. Se nunca antes tiver encontrado o patógeno, o sistema imunitário inicialmente é apanhado de surpresa e demora algum tempo a mobilizar as suas defesas para lançar um contra-ataque.

\section{O mecanismo de reprodução: replicação}

Os vírus são as menores entidades suscetíveis de se auto-replicarem, contendo DNA ou RNA. É como se satisfizessem apenas os requisitos mais básicos, mais restritos, de uma definição molecular da vida. Consequentemente, têm necessidade de infetar uma célula que lhes forneça os sistemas de síntese e as fontes de energia de que são desprovidos. A multiplicação no interior das células é um processo de replicação e não divisão. A partícula viral é reconstruída em múltiplos exemplares pelo auto-acoplamento de diferentes componentes que a célula produz, sob o controle do genoma viral. Segundo Agut (2007), o controle viral sobre o funcionamento celular é universal, tanto no caso de vírus de células eucarióticas como no caso de vírus de bactérias, chamados fagos. A infeção viral impõe outros modos de funcionamento que levam à disfunção da engrenagem celular. Essa 
originalidade traduz-se no recurso a enzimas específicas, geralmente, ausentes da célula e que são codificadas por genes virais.

O desvirtuamente das sínteses celulares pelo vírus tem consequências nefastas para o funcionamento da célula infetada. Alguns componentes do vírus podem induzir um efeito tóxico direto. Uma das alterações mais espetaculares é a transformação celular, ou seja, a aquisição pela célula infetada de propriedades das células cancerosas como, por exemplo, a imortalidade e a proliferação não controlada.

\section{Um caso de equilíbrio na interação no sistema vírus-hospedeiro?}

O coelho-europeu Oryctolagus cuniculus foi introduzido na Austrália em 1879, com o objetivo de servir de caça e entretenimento para colonizadores ricos. Rapidamente se espalhou por todo o território australiano, tornando-se na maior praga animal. O caso foi tão crítico que levou as autoridades a implementar uma série de medidas de controlo desta espécie invasora, incluindo o controlo biológico.

O controlo biológico, recorrendo ao vírus da mixomatose (MYXV), nos anos 1950, teve resultados de elevada eficácia no início da sua implementação. Numa fase inicial, os coelhos morriam uma ou duas semanas após serem infetados com o vírus MYXV. Hoje, o vírus mata os coelhos apenas ocasionalmente, mas só após vários meses, e não semanas. Esta mudança deve-se à redução da sua virulência em conjunto com a evolução da resistência ao vírus pela parte dos coelhos.

Robert May e Roy Anderson, dois biólogos populacionais, estudaram este caso e concluíram que é compensador para o parasita não matar o seu hospedeiro, mas compensa igualmente que o parasita seja eficiente a transferir-se para novos hospedeiros: a tendência é maximizar o produto destes dois fatores, sobrevivência do hospedeiro e infetividade (May \& Anderson, 1983). Muito provavelmente, o sistema vírus-hospedeiro atingiu uma espécie de compromisso entre a virulência e a transmissibilidade: o vírus transmite-se facilmente, conservando o nível de virulência ainda bastante elevado, mas mais reduzido que na fase inicial (Pracontal, 1995). Numa estratégia de sobrevivência de longo prazo, o melhor é evoluir a caminho da avirulência, tendo como resultado uma infeção ligeira ou que mal se deteta, no hospedeiro. Mas para que isso aconteça, o sistema imunitário do hospedeiro deve primeiro encontrar uma maneira de dominar o parasita.

$O$ vírus da mixomatose é originário da América do Sul, cujo hospedeiro natural é o coelho-do-mato brasileiro (Sylvilagus brasiliensis), espécie à qual raramente causa sintomas letais. Na Europa, em 1952, o médico francês, então reformado, Paul-Félix-Delille, com o objetivo de eliminar os coelhos que lhe estavam a causar estragos na sua propriedade, introduziu de forma ilegal o vírus da mixomatose, através da inoculação de dois coelhos. O MYXV, uma vez que é facilmente 
transmitido por mosquitos e pulgas, espalhou-se rapidamente por toda a França e outras partes da Europa, incluindo o Reino Unido, Portugal e Espanha, resultando na morte de cerca de $90 \%$ do efetivo populacional de O. cuniculus. Em 1986, as populações de $O$. cuniculus começaram, finalmente, a ganhar resistência ao vírus da mixomatose e a recuperar. Infelizmente, por essa altura, o vírus da doença hemorrágica viral RHDV (que surgiu na China em 1984) chegou à Europa, culminando numa nova redução das populações de coelhos em 55-75\% na Península Ibérica.

$\mathrm{O}$ vírus da doença hemorrágica viral transmite-se por contacto direto e os coelhos adultos são mais suscetíveis que os juvenis, contrariamente ao vírus da mixomatose. Mais recentemente, surgiu uma variante do vírus RHDV, que é mais letal que a variante original e, para além, de indivíduos adultos, afeta juvenis a partir dos 11 anos de idade e está a ameaçar ainda mais o tão frágil efetivo populacional de O. cuniculis da Península Ibérica. Neste caso, se é apenas danificando o hospedeiro que o parasita consegue uma elevada capacidade de infetar, então não devemos esperar a evolução no sentido do comensalismo inofensivo.

\section{Nem todos os vírus são "maus": uma mudança de paradigma}

A história médica recente providencia um catálogo de fracassos (Miller, 2021). Por exemplo, nenhum laboratório conseguiu desenvolver até hoje vacinas eficazes contra o VIH porque este vírus de RNA consegue gerar rápidas mutações. Uma vacina que confere proteção contra uma versão do VIH é, muitas vezes, inútil contra outra. Existe uma grande diversidade genética no VIH. A seguir ao seu aparecimento nos anos 1980, terapias inovadoras conseguiram reduzir significativamente a letalidade do patógeno, mas nenhuma vacina alcançou uma proteção suficiente.

A variabilidade genética é um exemplo de mecanismo de fuga da resposta imunológica selecionado nos vírus, resultando diretamente da replicação de genomas. Felizmente, os progressos da genómica transformaram os vírus em vetores genéticos úteis para as vacinas recombinantes e, também, para a terapia génica (Calafate, 2021). A deficiência imunológica de "bebés-bolha", ou "criançasbolha", pode ser reparada recorrendo a um vetor retroviral.

A nossa relação com os vírus tem evoluído com o conhecimento acerca da quantidade e diversidade de vírus no planeta. Os vírus marinhos desempenham um papel crucial na dinâmica das populações de microrganismos e, consequentemente, influenciam os ecossistemas. O novo paradigma de "shunt" viral está a contribuir para uma nova visão e compreensão do impacto dos vírus à escala do clima (Fuhrman, 1999). 
Os novos paradigmas desenvolvem-se devido à ação de cientistas criadores à medida que velhos paradigmas se tornam insuficientes nas suas explicações. Mas esta mudança, segundo Kuhn (1980), não se efetua de um modo contínuo e progressivo mas, ao contrário, por ruturas. Segundo uma conceção de Kuhn, datada de 1978, o conceito de paradigma representa um esquema concetual através do qual um cientista, numa determinada disciplina, elabora problemas. Os problemas a investigar e os métodos a serem utilizados para os resolver são determinados pelos paradigmas que são aceites pela comunidade científica. A comunidade científica tem o monopólio do paradigma e filtra a inovação à luz das suas representações. Kuhn (1979) chega mesmo a afirmar que é um mito a ideia de que existe liberdade de criação científica e que são poucos aqueles que acreditam que ser científico é, entre outras coisas, ser objetivo e ter espírito aberto.

\section{A descoberta da "transcrição reversa": o desafiar de um "dogma"}

Segundo Chastel (2007), o ano de 1970 foi marcado pela descoberta revolucionária de uma enzima viral, a "transcriptase reversa" (ou retrotranscriptase). Howard Temin e David Baltimore, dois virologistas americanos, demonstraram que essa enzima é capaz de transcrever uma mensagem genética RNA numa mensagem DNA. Esta integra em seguida um cromossoma da célula hospedeira, e inverte a evolução comummente admitida de informação genética, a saber de DNA para RNA. Foi um considerável salto em termos de Genética Molecular relativamente a teorias de transferência de informação nos sistemas biológicos, partilhadas pelos membros da comunidade científica (Baltimore, 1970; Temin \& Mituzani, 1970).

Depois de Renato Dulbecco descobrir que os vírus que provocam tumores operam incorporando o seu DNA no DNA das células hospedeiras, Howard Temin e David Baltimore, independentemente um do outro, descobriram que os vírus com genomas de RNA também o podem inserir no DNA das células hospedeiras (Dulbecco, 1995). Até à descoberta da enzima "reverse transcriptase", que desafiou o dogma central da Biologia Molecular, Temin foi vítima de sarcasmo, quando apresentou em 1969 aos seus colegas a hipótese do "protovírus" (Kupiec, 1995). Todavia, a quebra deste paradigma por Temin e Baltimore teve uma grande ressonância na investigação, por exemplo, numa altura em que havia um grande interesse acerca da origem da vida na Terra.

Para além dos oncovírus, o vírus da imunodeficiência humana (VIH) também é um retrovírus, uma família de vírus de RNA cujo ciclo biológico compreende uma fase particular - a retrotranscrição - que converte o RNA viral em DNA e permite a sua integração no DNA da célula hospedeira (Maréchal, 2007). A partir daí, manipula a célula de maneira a criar novos vírus que 
conseguem escapar e infetar outros linfócitos T CD4. Assim que o VIH entra no organismo de uma pessoa, ataca o próprio sistema imunitário, desafiando até aos dias de hoje a corrida às armas pela comunidade médica e de investigadores, no que respeita à criação de vacinas.

\section{Fagos oceânicos: impacto ambiental}

Existe na Terra uma gigantesca reserva de vírus. Ainda não temos estimativas fidedignas para a massa terrestre, mas quando começaram a ser realizadas amostras com água do mar, os resultados revelaram-se surpreendentes. Foram estimados 100 mil milhões de partículas virais em cada litro de água do mar. Numa colheita de 200 litros de água do mar encontraram-se 5000 diferentes vírus, 90\% dos quais desconhecidos. Atualmente sabemos que $94 \%$ de todas as partículas de água do mar são fagos, mas essa abundância só começou a tornar-se patente no final da década de 80 , quando passaram a ser procurados e identificados de forma sistemática por equipas de microbiologistas (Sullivan, Weitz \& Wilhelm, 2016).

Com o trabalho de Wilhelm \& Suttle (1999) tornou-se evidente que os vírus desempenham um papel relevante na ecologia dos oceanos. Os fagos oceânicos eliminam, diariamente, 20 a $40 \%$ dos procariotas que habitam na superfície do oceano. Não mantêm apenas controladas as populações destes microrganismos, mas também regulam a disponibilidade de nutrientes. Quando um fago infeta um procarionte provoca lise celular e, devido à rotura da membrana celular, ocorre a libertação do seu material genético e de outros nutrientes como, por exemplo, o ferro.

Um dos elementos que escasseia no oceano é o ferro, pois é, praticamente, insolúvel na água. Contudo, o ferro proveniente das lises celulares, é organicamente complexo e solúvel, podendo ser absorvido por outros organismos. Ou seja, as infeções provocadas pelos fagos proporcionam a disponibilidade de um nutriente essencial ao funcionamento do ecossistema marinho, tendo um papel determinante nos ciclos biogeoquímicos à escala global (Sullivan, Weitz \& Wilhelm, 2016). Portanto, os bacteriófagos são essenciais para manter os ecossistemas aquáticos saudáveis. Um em particular, o $\mathrm{HTVC}_{010} \mathrm{P}$, é o mais abundante e infeta uma das bactérias mais comuns nos meios marinhos, a Candidatus Pelagibacter communis (Du et al., 2021).

Em resumo, atendendo à sua quantidade nos ambientes aquáticos, não é surpreendente que os vírus desempenhem um papel significativo na biosfera e tenham um elevado potencial para provocar mudanças nos ecossistemas do planeta Terra (Zimmer, 2021). De facto, há milhões de anos que desempenham um papel crucial na evolução da própria vida. 


\section{Um "fenótipo de Fénix"}

Os vírus ocupam um mundo misterioso situado entre a vida e a ausência de vida. Nesse espaço estranho, às vezes, surpreendem. Alguns vírus chegam a multiplicar-se no interior de células mortas e, até mesmo, a ressuscitá-las (Villarreal, 2007)!

Uma célula cujo DNA nuclear foi destruído está condenada. Sem esse DNA, a célula fica desprovida das instruções genéticas necessárias à produção de proteínas e à sua multiplicação. No entanto, um vírus aproveita a engrenagem celular para se replicar, obrigando essa engrenagem a utilizar os seus próprios genes como guia para a síntese das suas proteínas virais e para a replicação do genoma viral.

Esta capacidade dos vírus para crescer num organismo morto manifesta-se em hospedeiros unicelulares, cuja maioria vive nos oceanos. As bactérias, assim como as cianobactérias e as algas fotossintéticas, são em geral mortas quando a radiação ultravioleta destrói o seu DNA nuclear. Alguns vírus, que colonizam essas células, codificam enzimas que reparam diversas moléculas da célula hospedeira, trazendoos de volta à vida.

As cianobactérias contêm uma enzima que funciona como um centro fotossintético, mas que pode ser destruído pelo excesso de luz. Quando isso acontece, a célula morre, pois é incapaz de continuar a fotossíntese, e o seu metabolismo deixa de funcionar. Todavia, os cianofagos codificam a sua própria versão da enzima bacteriana de fotossíntese. Essa versão viral é muito mais resistente à radiação ultravioleta. Se esses vírus infetam uma célula recémdestruída, a enzima viral da fotossíntese substitui a perdida pela célula hospedeira. É uma autêntica terapia génica emergencial.

Uma quantidade suficiente de radiação ultravioleta pode, apesar de tudo, destruir os cianofagos. Não obstante, esses vírus podem, algumas vezes, recuperar a vida das células hospedeiras. Essa "ressurreição" produz-se devido a um processo chamado de reativação por multiplicidade: quando uma célula contém mais de um vírus inativo, o genoma viral é capaz de se agregar a partir de fragmentos. As diversas partes do genoma, algumas vezes, também fornecem genes que empreendem uma ação combinada, dita de complementação, que garante a função global, sem necessariamente formar um vírus completo ou autónomo.

Em suma, podemos admitir que os vírus são as únicas entidades dotadas de um "fenótipo de fénix", ou seja, da capacidade de renascer das próprias cinzas, à semelhança do pássaro da mitologia grega.

\section{A descoberta dos Mimivírus e Pandoravírus: uma revolução?}

A equipa de Jean-Michel Claverie descobriu em 1992 um vírus das amebas os Mimivírus (La Scola et al., 2003). Didier Raoult e seus colaboradores (La Scola et al., 2003), da Universidade de Marselha, determinaram a sequência do genoma 
do Mimivírus. Este vírus, que tem, aproximadamente, o tamanho de uma bactéria, infeta as amebas. Segundo os biólogos marselheses, o tamanho e a complexidade do genoma do Mimivírus tornam ainda mais ténue a fronteira estabelecida entre os vírus e os organismos celulares parasitas.

Entretanto, a equipa de Jean-Michel Claverie e colegas das Universidades de Uppsala (Suécia) e Grenoble (França) descobriram novos vírus ainda maiores que o Mimivírus. Batizaram-nos Pandoravírus, numa referência ao mito grego de Pandora (Philippe et al., 2013). São visíveis ao microscópio ótico e são maiores que as bactérias!

As ciências progridem através de saltos e ressaltos. Dentro do desenvolvimento do campo científico da Virologia, eventualmente, estaremos a assistir a uma transição do período pré- para o pós-paradigma. Por exemplo, com a descoberta do Mimivírus, sabemos agora que os vírus formam um ramo separado das outras três formas de vida: os eucariotas, as bactérias e os archea. Nesta genealogia, onde se situam os vírus? Serão um quarto ramo da árvore da vida? Mais importante ainda: a descoberta da Virosfera mudou efetivamente a imagem que hoje temos da vida e do próprio Planeta Terra.

\section{Conclusão}

Atualmente, é difícil não estar de acordo quando se trata de negar uma conceção de Ciência que supõe uma produção de conhecimento linear, cumulativa, obtida através de um método científico, com o qual se descobre a realidade dos fenómenos a partir única e exclusivamente deles próprios. Relativamente à influência das preconceções na construção do conhecimento na história da ciência podemos encontrar alguns exemplos. Max Planck não quis durante muito tempo admitir o que era a sua grande descoberta, tentando durante anos corrigir os cálculos pois estava convencido de que havia um erro. Só mais tarde, passados dois ou três anos de tentativas falhadas para negar o que era um dos factos científicos mais revolucionários do século XX, é que veio a admitir a sua descoberta dos quanta de luz. Erwin Schrodinger afirmava que preferia abandonar a sua carreira de físico a aceitar o princípio da descontinuidade. Também Albert Einstein, quanto à Mecânica Quântica, dizia a Werner Heisenberg que estava de acordo com os seus resultados experimentais, mas que se recusava a aceitar que tal modelo pudesse servir para uma descrição final da Natureza. Era Einstein quem afirmava, perante o princípio do indeterminismo, que não acreditava que Deus jogasse aos dados (Calafate, 1984).

Numa perspetiva anti-empirista, Thomas Kuhn (1980) identificou dois tipos de atividade científica. A atividade que caracteriza a maior parte do trabalho dos cientistas, quando eles realizam experiências e procedem a observações, designoua por ciência normal e o outro tipo de atividade, que é menos comum e a maior 
parte dos cientistas nunca contribui para ele, pois apenas raros génios criadores são capazes de inventar novos paradigmas, designou-a por ciência revolucionária. A ciência normal é aquela que se desenrola segundo os moldes de um determinado paradigma preocupando-se muito pouco com a descoberta de novidades tanto no plano concetual como no plano dos fenómenos. A pesquisa orienta-se na intenção de criar problemas cuja solução é previsível e cuja solução irá corroborar a pertinência do paradigma em questão. Trata-se então, no dizer de Kuhn, da resolução de "puzzles" e o que é problemático é o modo de chegar ao resultado final. O modo como se criam tais "puzzles" e a forma de os solucionar obedece a regras que limitam o âmbito dos problemas possíveis e definem o horizonte do resultado. Estas regras são pontos de vista ou preconceções. A atividade científica está de tal modo enquadrada pelos limites concetuais do paradigma em vigor que sempre que um homem de ciência falha na solução de um destes problemas considera-se o acontecimento como um fracasso individual e não como uma insuficiência da teoria. A ciência revolucionária surge quando são obtidos resultados conflituosos ou quando os paradigmas são insuficientes na sua aplicação a um grupo de problemas importantes. Neste caso, um novo paradigma é inventado e estamos perante uma revolução científica. Portanto, o desenvolvimento da ciência é caraterizado por Kuhn (1980) como uma sucessão de períodos, mais ou menos longos, de ciência normal com intervalos de ciência revolucionária. Durante a ciência normal os instrumentos técnico-científicos são refinados e uma variada gama de exemplos é estudada. Durante a fase revolucionária, um novo paradigma é criado e novos problemas são formulados.

Vivemos num planeta pouco conhecido e, só muito recentemente, descobrimos que a Terra é um "Planeta de Vírus" (Zimmer, 2021). Por exemplo, no mar existe uma superabundância de bacteriófagos, conhecidos apenas em 2013. Até então, os especialistas julgavam que os micropredadores do género eram relativamente raros. Todavia, novos métodos no domínio ultramicroscópico revelou a presença de vírus numa média de mil milhões por litro de água do mar (Wilson, 2019). Em suma, partilhamos o planeta Terra com os vírus (Marçal \& Fiolhais, 2020).

Neste contexto, é necessário ajudar as pessoas a compreender melhor a "Virosfera", preparando-as para a singularidade, por exemplo, dos retrovírus endógenos humanos (HERV), que infetam as células reprodutoras. Hoje, sabemos que os nossos genes também são genes retrovirais! Originalmente, os mamíferos reproduziam-se através de ovos, como o continuam a fazer os ornitorrincos. A certa altura, o antecessor dos atuais mamíferos foi infetado por um retrovírus que conseguiu, eventualmente, alterar a estrutura da membrana interior do ovo, transformando-a numa placenta. De facto, sem essa infeção ancestral, não poderíamos ter usufruído do desenvolvimento intrauterino (Villarreal, 2016). 
Como todos os seres vivos, o homem faz parte de um sistema ecológico complexo e está ligado a todas as suas componentes por inúmeros laços e interações. $\mathrm{O}$ aumento de interesse pelo mundo viral acontece em paralelo a uma reavaliação da importância dos vírus na biosfera atual. Sem eles e sem os restantes microorganismos, os seres humanos não existiriam e não haveria vestígios de vida. Nem sequer teria surgido uma atmosfera respirável. Não devemos cometer o erro comum de pensar que todos os vírus são maus. Para cada vírus nocivo há milhões em nós que são aparentemente inofensivos, e alguns podem ser úteis ou mesmo essenciais. É de realçar que uma parte considerável do nosso conhecimento atual na área da biologia celular de eucariotas advém do estudo dos vírus. Não há razão para desconfiarmos da ciência (Oreskes, 2021).

\section{Referências}

Agut, H. (2007). La multiplication des virus. Pour La Science, 55, 14-19.

Aires, L. M. (2020). Virus, Bactérias e Humanos. Ciência e Histórias de uma Coabitação Atribulada. Lisboa: Edições Sílabo.

Baltimore, D. (1970). Viral RNA-dependent DNA Polymerase: RNA-dependent DNA Polymerase in Virions of RNA Tumour Viruses. Nature, 226, 1209-1211.

Calafate, L. C. (1984). Estudo das Implicações da Epistemologia da Ciência na Epistemologia Escolar. (Provas de aptidão pedagógica e capacidade científica, não publicadas). Faculdade de Ciências da Universidade do Porto, Portugal.

Calafate, S. (2021). Vírus de laboratório. Rev. Ciência Elem., V9(2), 031

Chastel, C. (2007). La découverte d'un nouveau monde. Pour La Science, 55, 8-13.

Dennett, D. C. (2021). Das bactérias a Bach e vice-versa. A evolução das mentes. Lisboa: Edições 70.

Diamond, J. (2002). Armas, Germes e Aço. Os Destinos das Sociedades Humanas. Relógio D’Água Editores.

Du, S., Qin, F., Zhang, Z., Tian, Z., Yang, M., Liu, X., Zhao, G., Xia, Q., \& Zhao, Y. (2021). Genomic diversity, life strategies and ecology of marine HTVC010P-type pelagiphages. Microbial Genomics, 7, 000596

Dulbecco, R. (1995). "Howard M. Temin, 10 December 1934 - 9 February 1994". Biographical Memoirs of Fellows of the Royal Society, 41(4), 471-80. 
Fuhrman, J. A. (1999). Marine viruses and their biogeochemical and ecological effects. Nature, 399, 541-548.

Honigsbaum, M. (2021). O Século das Pandemias. Amadora: Vogais.

Kuhn, T. (1978). Segundos Pensamentos Sobre Paradigmas. Madrid: Tecnos.

Kuhn, T. (1979). A Função do Dogma na Investigação Científica. In M.M. Carrilho (Ed.) História e Prática das Ciências. Lisboa: A Regra do Jogo.

Kuhn, T. (1980). La estrutura de las revoluciones científicas. Madrid: Fondo de Cultura Económica.

Kupiec, J.-J. (1995). Histoire de vírus, de gènes et de chercheurs. Science et Vie, $193,56-65$.

La Scola, B., Audic, S, Robert, C., Jungang, L., de Lamberie, X., Drancourt, M., Birtles, R., Claverie, J.-M., \& Raoult, D. (2003). A Giant Virus in Amoebae. Science, 299, 2033.

Marçal, D., \& Fiolhais, C. (2020). Apanhados pelo Virus. Lisboa: Gradiva.

Maréchal, V. (2007). Virus en emboscade dans l'organisme. Pour La Science, 55, 66-71.

May, R. M., \& Anderson, R. M. (1983). Epidemiology and genetics in the coevolution of parasites and hosts. Proc. R. Soc. London, 219, 281-313.

Maynard Smith, J., \& Szathmáry, E. (2007). As Origens da Vida. Do Nascimento da Vida às Origens da Linguagem. Lisboa: Gradiva.

Miller, J. (2021). A Vacina: A Inovação de uma Era no combate à COVID-19. Lisboa: ACTUAL.

Misasi, J., \& Sullivan, N.J. (2014). Camouflage and Misdirection: The Full-On Assault of Ebola Virus Disease. Cell, 159(3), 477-486.

Oreskes, N. (2021). Porque confiar na ciência? Lisboa: Gradiva.

Parreira, R., \& Piedade, J. (2016). Vírus. In W.F.C. Ferreira, J.C.F. de Sousa and N. Lima (Eds.), Microbiologia (pp. 110-129). Lisboa: Lidel.

Philippe, N., Legendre, M., Doutre, G., Couté, Y., Poirot, O., Lescot, M., Arslan, D., Seltzer, V., Bertaux, L., \& Bruley, Ch. (2013). Pandoraviruses: Amoeba Viruses with Genomes Up to $2.5 \mathrm{Mb}$ Reaching That of parasitic Eukariotes. Science, 341, 281-286.

Pilorge, T. (1995). Une brève histoire de l'infiniment Petit. Science et Vie, 193: 4-9.

Popper, K. (1978). La Logique de la Découverte Scientifique. Paris: Payout.

Pracontal, M. (1995). Les Gendarmes d'Atlanta contre le vírus. Science et Vie, 193, 80-89.

Sonigo, P. (1995). Durer: l'unique raison d'être des Vírus. Science \& Vie, 193, 66-74.

Sullivan, M. B., Weitz, J. S., \& Wilhelm, S. (2016). Viral ecology comes of age. Environmental Microbiology Reports, 9(1), 33-35. 
Tavares, M. (2007). Gripe. Matosinhos: QuidNovi.

Temin, H. M., \& Mituzani, S. (1970). RNA-dependent DNA Polymerase in Virions of Rous Sarcoma Virus. Nature, 226, 1211-1213.

Villarreal, L. (2007). Les vírus sont-ils vivants? Pour La Science, 55, 20-24.

Villarreal, L. (2016). Viruses and the placenta: the essential vírus first view. APMIS, 124, 20-30.

Wilhelm, S. W., \& Suttle, C. A. (1999). Viruses and nutrient cycles in the seaviruses play critical roles in the structure and function of aquatic food webs. Bioscience, 49, 781-788.

Wilson, E. O. (2019). Da Terra Metade. A Luta do Nosso Planeta pela Vida. Porto: Arte E Ciência.

Whitfield, P. (1994). História Natural da Evolução. Lisboa: Verbo.

Zimmer, C. (2021). Um Planeta de Virus. Porto Salvo: Desassossego. 